\title{
NOTE
}

\section{JAGUAR (PANTHERA ONCA) IN THE STATE OF MEXICO}

\author{
Octavio Monroy-Vilchis, * Óscar Sánchez, Ulises Aguilera-Reyes, Pedro Suárez, and \\ VICENTE URIOS
}

\author{
Estación Biológica Sierra Nanchititla, Facultad de Ciencias, Universidad Autónoma del Estado de México, Instituto \\ Literario 100, Colonia Centro, 50000, Toluca, México (OM-V, UA-R, PS) \\ Estación Biológica Terra Natura, Centro Iberoamericano de la Biodiversidad, Universidad de Alicante, Fundación Terra \\ Natura, Apartado 99, 03080 Alicante, Spain (VU) \\ Consultor Científico en Conservación de Vida Silvestre, Avenida Ixtlahuaca 609, Colonia Sánchez, Toluca 50040, \\ México (OS) \\ *Correspondent: omv@uaemex.mx
}

\begin{abstract}
We document the jaguar (Panthera onca) in the Sierra Nanchititla (state of Mexico) in pine-oak forest. During October 2002-December 2004, we determined presence of jaguars using three methods: we conducted interviews in local communities, collected scats, and installed automatedcamera detection systems. Although no jaguar was mentioned in 86 interviews, 3 photographs of a male were obtained, and 10 of 132 scats were attributed to $P$. onca. This represents the first record of $P$. onca in central Mexico within the Balsas River macro-basin.

RESUMEN-Documentamos la presencia de jaguar (Panthera onca) en la Sierra Nanchititla (estado de México) en bosque de pino-encino. De octubre 2002 a diciembre 2004, evaluamos la presencia del jaguar usando tres métodos: condujimos entrevistas en comunidades locales, colectamos excrementos, e instalamos sistemas automáticos de detección fotográfica. Aunque en 86 entrevistas no se mencionaron jaguares, obtuvimos 3 fotografias de un macho y 10 de 132 excrementos fueron atribuibles a $P$. onca. Este representa el primer registro de $P$. onca en el centro de México dentro de la macrocuenca del río Balsas.
\end{abstract}

The jaguar (Panthera onca) is a species of global conservation concern. It is listed in Appendix I of CITES (United Nations Environment Programme-World Conservation Monitoring Centre, http://www.cites.org) and has been ranked as near threatened by the International Union for the Conservation of Nature (http:// www.iucnredlist.org) and as endangered in Mexico (Secretaria del Medio Ambiente y Recursos Naturales, 2002). Populations are threatened mainly due to fragmentation, deterioration, and loss of habitat, but also by hunting, illegal trafficking, and competition with humans (Jorgenson and Redford, 1993; Leite and Galvão, 2002).

Since 1995, several researchers have added to our understanding of the geographical distribution of $P$. onca in Mexico (Téllez-Girón and López-Forment, 1995; López Soto et al., 1997;
Moreno-Valdez, 1998; Ortega-Huerta and Medley, 1999; López-González and Brown, 2002; Rosas-Rosas and López-Soto, 2002; Valdez et al., 2002). Records from central Mexico include a specimen (MZFC-M 3459) at the Museo de Zoología, Facultad de Ciencias (Universidad Nacional Autónoma de México), from cloud forest and pine-oak forest at 2,500 $\mathrm{m}$ in the state of Guerrero, $3 \mathrm{~km} \mathrm{~S}$ Puerto del Gallo in the Sierra Madre del Sur (Navarro-Sigüenza, 1986; León and Romo, 1991; Red Mundial de Información sobre Biodiversidad, http://www.conabio. gob.mx/remib/cgi-bin/remib_distribucion.cgi). López-Wilchis and López-Jardines (1998) reported a specimen from the state of Morelos in the United States National Museum of Natural History; however, R. López-Wilchis (pers. comm.) told us that the locality and date of collection of that specimen appear suspect. C. 
Ludwig (in litt.) recently confirmed that the museum does not have a specimen of $P$. onca from Morelos.

Thus, no published record of $P$. onca from the state of Mexico exists. Various authors doubted the presence of jaguars in the pineoak forest of the Transverse Neovolcanic Belt (Nowell and Jackson, 1996; Sanderson et al., 2002a), and others have stated than no jaguar has existed in central Mexico since the beginning of the past century (W. G. Swank and J. G. Teer, in litt.).

We previously investigated wild felids in the state of Mexico and recorded the presence of Leopardus pardalis, Leopardus wiedii, Puma concolor, Lynx rufus, and Herpailurus yagouaroundi (Sánchez et al., 2002). Subsequent surveys in the southwestern part of the same state have confirmed the continuous presence of $P$. concolor, L. pardalis, L. wiedii, and $H$. yagouaroundi. Based on these findings, we started the second stage of our project, with the aim of monitoring the presence of felids and re-assessing the possible presence of $P$. onca.

The study was performed in the Reserva Natural Sierra Nanchititla, an area of $674,10 \mathrm{~km}^{2}$ in the Sierra Nanchititla in the southwestern part of the state of Mexico. The study area ranged in elevation from 400 to $2,080 \mathrm{~m}$ and was located $18^{\circ} 45^{\prime} 38^{\prime \prime}-19^{\circ} 4^{\prime} 13^{\prime \prime} \mathrm{N}$, $100^{\circ} 15^{\prime} 59^{\prime \prime}-100^{\circ} 36^{\prime} 34^{\prime \prime} \mathrm{W}$. Deciduous tropical forest is common in the Balsas River Basin (format elevations of 400-1,400 m), and pine-oak forests characterize the Transverse Neovolcanic Belt at 1,400-2,080 m. Climate in the Reserva Natural Sierra Nanchititla ranges from temperate subhumid at elevations $\geq 1,400 \mathrm{~m}$ to hot sub-humid at $<1,400 \mathrm{~m}$ (García, 1988). The nearest large human settlement (Tejupilco) is $65 \mathrm{~km}$ east by road from the Reserva Natural Sierra Nanchititla and has ca. 85,000 inhabitants (Instituto Nacional de Estadistica Geografia e Informacion, http://www.INEGI.gob.mx).

We conducted our research October 2002December 2004, using three complementary methods;: interviews of local inhabitants, using regional names for wild cats and images of all species of Mexican cats; collection of scats; and automated photography at locations where felids had been detected during our previous work in the Reserva Natural Sierra Nanchititla.

We visited local communities on 12 occasions, every 20 days. We questioned farmers, cattle ranchers, forest rangers, hunters, and other local inhabitants about local sightings during the past 2 decades, and we asked them to show us any skins or other remains of jaguars in their possession. We walked ca. 1,360 km along trails and collected scats identified as those of felids. During December 2003-December 2004, we placed five motion-sensitive, automatic, photodetection systems (Wildlife Pro II Camera System T5D with Carl Zeiss T*-Tessar 3.5/35 optics with an interval chronometer manufactured by Yashica, Hong Kong, China) and 400 and 800 ASA color print film in a variety of locations. Cameras were programmed for an 18-s-interval between frames, and film was changed every 20 days. We tied cameras to tree-trunks $1-3 \mathrm{~m}$ from trails where footprints, scats, or both had been found previously. Distances between cameras were 4$13 \mathrm{~km}$. For each photographic-detection event we recorded date, latitude, longitude, elevation, and coverage percentages (by vegetation stratum). Each location was mapped.

We conducted 86 interviews in 11 local communities. Age of interviewees averaged 49 years and ranged from 18 to 78 . We received information about 109 sightings of cats during 1982-2004, of which 34 cats were described as spotted, but not representing $P$. onca. We did not find jaguar skins or remains in possession of local inhabitants.

We collected 132 scats and compared their diameters with known intervals for $P$. onca and $P$. concolor following criteria developed by Aranda (2000). We attributed 10 scats (Table 1 ) to $P$. onca because of their large diameter (35.01$38.84 \mathrm{~mm}$, mean $36.37 \pm 1.29 \mathrm{~mm} \mathrm{SD)}$. This mean does not overlap with the maximum diameter reported for $P$. concolor by Aranda (2000). Furthermore, the diameter of the smallest scat attributed to the jaguar in Reserva Natural Sierra Nanchititla is larger than the largest values of the scats attributed to Puma by Aranda (2000).

Our cameras recorded 1,800 events. Three photographs, deposited in the collection of mammal images of the Estación Biológica Sierra Nanchititla, Universidad Autónoma del Estado de México, depicted a male jaguar (genitalia clearly visible). The first image, from 14 November 2004 at $0049 \mathrm{~h}$ (photograph EBSN-UAEMex 00010 ), shows the cat walking along the trail. The other two photographs were taken 20 days after the first; in one, the individual stopped to 
TABle 1-Records of the jaguar (Panthera onca) in the Reserva Natural Sierra de Nanchititla, state of Mexico, Mexico, 28 October 2002-28 December 2004.

\begin{tabular}{llcc}
\hline \hline \multicolumn{1}{c}{ Record } & Locality & Global position & Elevation $(\mathrm{m})$ \\
\hline Scat & Bancos & $18^{\circ} 50^{\prime} 0.3^{\prime \prime} \mathrm{N}, 100^{\circ} 25^{\prime} 51.8^{\prime \prime} \mathrm{W}$ & $1,868 \pm 6.7$ \\
Scat & Cascada & $18^{\circ} 49^{\prime} 26.6^{\prime \prime} \mathrm{N}, 100^{\circ} 25^{\prime} 39.9^{\prime \prime} \mathrm{W}$ & $1,471 \pm 4.1$ \\
Scat & Mesa Alta & $18^{\circ} 51^{\prime} 9.6^{\prime \prime} \mathrm{N}, 100^{\circ} 24^{\prime} 25.7^{\prime \prime} \mathrm{W}$ & $1,859 \pm 9.9$ \\
Scat & Cerro Alto & $18^{\circ} 49^{\prime} 58.6^{\prime \prime} \mathrm{N}, 100^{\circ} 24^{\prime} 9.5^{\prime \prime} \mathrm{W}$ & $1,865 \pm 5.2$ \\
Scat & Mesa Alta & $18^{\circ} 51^{\prime} 10.0^{\prime \prime} \mathrm{N}, 100^{\circ} 24^{\prime} 37.1^{\prime \prime} \mathrm{W}$ & $1,830 \pm 5.3$ \\
Scat & Piedra & $18^{\circ} 49^{\prime} 26.7^{\prime \prime} \mathrm{N}, 100^{\circ} 25^{\prime} 16.5^{\prime \prime} \mathrm{W}$ & $1,523 \pm 10.1$ \\
Scat & Tinocos & $18^{\circ} 50^{\prime} 15.4^{\prime \prime} \mathrm{N}, 100^{\circ} 25^{\prime} 58.6^{\prime \prime} \mathrm{W}$ & $1,760 \pm 7.5$ \\
Scat & Picacho & $18^{\circ} 50^{\prime} 6.9^{\prime \prime} \mathrm{N}, 100^{\circ} 23^{\prime} 53.2^{\prime \prime} \mathrm{W}$ & $1,844 \pm 5.7$ \\
Scat & Bancos & $18^{\circ} 49^{\prime} 56.5^{\prime \prime} \mathrm{N}, 100^{\circ} 23^{\prime} 51.8^{\prime \prime} \mathrm{W}$ & $1,873 \pm 100$ \\
Scat & Bancos & $18^{\circ} 49^{\prime} 39.7^{\prime \prime} \mathrm{N}, 100^{\circ} 24^{\prime} 22^{\prime \prime} \mathrm{W}$ & $1,845 \pm 100$ \\
Photograph & Bancos & $18^{\circ} 49^{\prime} 39.7^{\prime \prime} \mathrm{N}, 100^{\circ} 24^{\prime} 22^{\prime \prime} \mathrm{W}$ & $1,845 \pm 100$ \\
Photograph & Bancos & $18^{\circ} 49^{\prime} 39.7^{\prime \prime} \mathrm{N}, 100^{\circ} 24^{\prime} 22^{\prime \prime} \mathrm{W}$ & $1,845 \pm 100$ \\
Photograph & Bancos & $18^{\circ} 49^{\prime} 39.7^{\prime \prime} \mathrm{N}, 100^{\circ} 24^{\prime} 22^{\prime \prime} \mathrm{W}$ & $1,845 \pm 100$ \\
\hline
\end{tabular}

smell the ground (EBSN-UAEMex 00011), and in the other, the jaguar turned around on the trail (EBNS-UAEMex 00012). Carefully comparing size and distribution of spots on the body, we concluded that the three photographs depicted one individual. The photographs were made at an elevation of $1,845 \mathrm{~m}$. $\quad\left(18^{\circ} 49^{\prime} 39.7^{\prime \prime} \mathrm{N}\right.$, $\left.100^{\circ} 24^{\prime} 22^{\prime \prime} \mathrm{W}\right)$ in temperate pine-oak forest with coverage consisting of $75 \%$ trees, $<1 \%$ shrubs, $20 \%$ herbaceous plants, and $<1 \%$ of mosses. The most abundant species of trees were Quercus magnoliifolia, Q. elliptica, Q. urbanii, and Pinus oocarpa. Photographs were taken on a trail that ran parallel to a 500-m high escarpment $400 \mathrm{~m}$ away for ca. $15 \mathrm{~km}$. There were two permanent watercourses (the Palos Prietos and El Salto rivers) and more than five temporary streams within a $10-\mathrm{km}$ radius of the camera.

No visual sighting or physical evidence of jaguars was reported by local residents. This lack of evidence might reflect that the jaguar is more elusive than other felids (Ortega-Huerta and Medley, 1999; Sunquist and Sunquist, 2002), or might imply that its presence in the area is sporadic, possibly related to availability of more characteristic habitat (tropical and subtropical scrub at $<1,200 \mathrm{~m}$; Sunquist and Sunquist, 2002) in nearby Michoacán and Guerrero, although $P$. onca is known from oak forests elsewhere (TéllezGirón and López Forment, 1995; Ortega-Huerta and Medley, 1999). The high elevation at which the male was recorded might support the suggestion that jaguars have resorted to traveling along mountain slopes because of habitat fragmentation, hunting, and other human activity at lower elevations (López-González and Brown, 2002; Valdez et al., 2002).

Repeated photographs of a single individual in a 20-day period (and subsequently), plus presence of scats at various places, might document part of the home range of this male. Further investigations might clarify whether the Sierra de Nanchititla is visited rarely by wandering jaguars or whether there is an established population of a small number of individuals.

Our documentation of at least one individual in the southwestern part of the state of Mexico extends the known distribution of $P$. onca ca. $400 \mathrm{~km}$ SSW Arroyo Seco, Querétaro, and 27 km NW Purísima de Arista (Téllez-Girón and López Forment, 1995), a locality described erroneously as $21^{\circ} 30^{\prime} \mathrm{N}$ and $100^{\circ} 42^{\prime} \mathrm{W}$, but actually ca. $21^{\circ} 30^{\prime} \mathrm{N}$ and $99^{\circ} 42^{\prime} \mathrm{W}$. It also extends the known range of the species ca. $140 \mathrm{~km}$ north of Puerto del Gallo (ca. $17^{\circ} 29^{\prime} \mathrm{N}$ and $100^{\circ} 11^{\prime} \mathrm{W}$ ), Guerrero.

This is the first documentation of the jaguar within the Balsas River Basin in central Mexico. The Wildlife Conservation Society considered the general region of the Balsas River Basin as a priority area for verifying the presence of $P$. onca (www.savethejaguar.com); the basin might represent a potential corridor for dispersal as described by Sanderson et al. (2002b). We suggest that further investigation of wild felids in central Mexico and particularly in the Balsas River basin is worthwhile. 

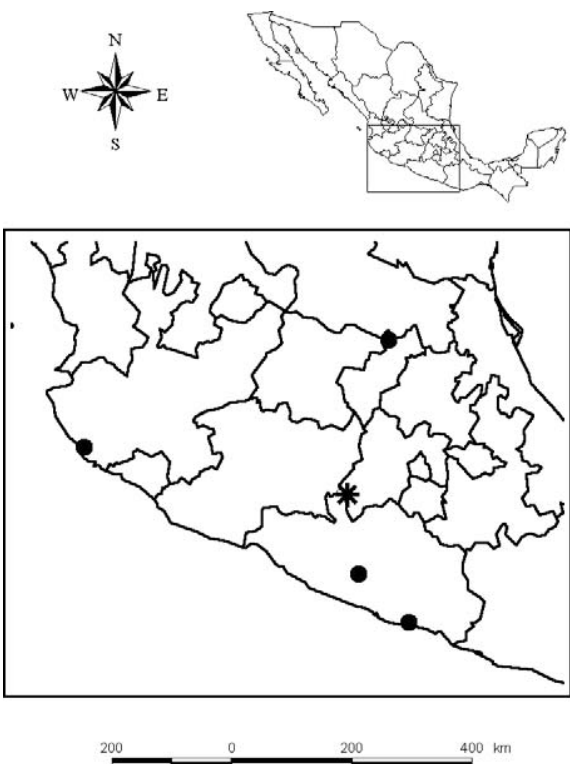

$400 \mathrm{~km}$

Fig. 1-Records of the jaguar (Panthera onca) near central Mexico (dots) and the locality reported herein (asterisk). Records from the Pacific drainage include the coasts of Jalisco (Chamela; Ceballos and Miranda, 1986), Guerrero (Acapulco; www.savethejaguar.com), and Michoacán (Coalcomán; Álvarez et al., 1987), as well as upland localities in Puerto del Gallo (Guerrero). The northernmost dot represents a record in the drainage of the Gulf of Mexico (Arroyo Seco in Querétaro).

This study was funded by the Mexican people through projects 1820/2004 and 2188/2005 (Universidad Autónoma del Estado de México) and by a doctoral scholarship (103.5/04/1304) to OM-V; the manuscript was derived from his dissertation. The Fundación Terra-Natura funded this study through project 2330/2006. The Comisión Estatal de Parques Naturales y de la Fauna, allowed access to the Reserva Natural Sierra Nanchititla. Local inhabitants in the vicinity of Nanchititla offered ample collaboration and valuable answers to field surveys. Students at the Estación Biológica Sierra de Nanchititla enthusiastically participated in fieldwork. OM-V thanks V. Vázquez for help in translation of parts of this text. We also thank C. A. Jones, H. Quigley, and an anonymous reviewer for comments that enriched the manuscript. OS acknowledges the interest of C. Breitenmoser (Cat Specialist Group, IUCN) in his research in Mexico, as well as the valuable assistance of M. Carleton and C. Ludwig (United States National Museum of Natural History), R. López-Wilchis (Universidad Autónoma Metropolitana-Iztapalapa), and L. León (Universidad Nacional Autónoma de México) who kindly provided critical data.

\section{Literature Cited}

Álvarez, T., J. Arroyo-C, and M. GonZÁlez-E. 1987. Mamíferos (excepto Chiroptera) de la costa de Michoacán, México. Anales Escuela Nacional de Ciencias Biológicas, México 31:13-62.

Aranda, M. 2000. Huellas y otros rastros de los mamíferos grandes y medianos de México. Conabio-Instituto de Ecología, A. C., Veracruz, México.

Ceballos, G., and A. Miranda. 1986. Los mamíferos de Chamela, Jalisco. Instituto de Biología, Universidad Nacional Autónoma de México, México.

García, E. 1988. Modificaciones al sistema de clasificación climática de Köppen: para adaptarlo a las condiciones particulares de la República Mexicana. Second edition. Instituto de Geografía, Universidad Nacional Autónoma de México, México.

Jorgenson, J. P., ANd K. H. RedFord. 1993. Humans and big cats as predators in the Neotropics. Symposia of the Royal Society of London 65:367-390.

Leite, M. R. P., AND F. Galvão. 2002. El jaguar, el puma y el hombre en tres áreas protegidas del bosque atlántico costero de Paraná, Brasil. Pages 237-250 in El jaguar en el nuevo milenio (R. A. Medellín, C. Equihua, C. L. B. Chetkiewicz, G. Crawshaw, JR, A. Rabinowitz, K. H. Redford, J. G. Robinson, E. W. Sanderson, and A. B. Taber, compilers, editors). Fondo de Cultura Económica, Universidad Nacional Autónoma y Ediciones Científicas Universitarias, México, D.F.

León-P, L., And E. Romo-V. 1991. Catálogo de mamíferos (Vertebrata: Mammalia). Catálogo 2. Serie Catálogos del Museo de Zoología "Alfonso L. Herrera," Facultad de Ciencias, Universidad Nacional Autónoma de México, México, D.F.

López-González, C. A., AND D. E. Brown. 2002. Distribución y estado de conservación actuales del jaguar en el noroeste de México. Pages 379-391 in El jaguar en el nuevo milenio (R. A. Medellín, C. Equihua, C. L. B. Chetkiewicz, G. Crawshaw, Jr., A. Rabinowitz, K. H. Redford, J. G. Robinson, E. W. Sanderson, and A. B. Taber, compilers, editors). Fondo de Cultura Económica, Universidad Nacional Autónoma y Ediciones Científicas Universitarias, México, D.F..

López-Soto, J. H., O. C. Rosas-Rosas, and J. A. Niño RAMírez. 1997. El jaguar (Panthera onca veraecrucis) en Nuevo León, México. Revista Mexicana de Mastozoología 2:126-128.

López-Wilchis, R., AND J. López Jardines. 1998. Los mamíferos de México depositados en colecciones de Estados Unidos y Canadá. Volume 1. Universidad Autónoma Metropolitana, Unidad Iztapalapa, México, D.F.

Moreno-Valdez, A. 1998. Mamíferos del Cañón del Huajuco, Municipio de Santiago, Nuevo León, México. Revista Mexicana de Mastozoología 3:5-25. 
Navarro-Sigüenza, A. G. 1986. Distribución altitudinal de las aves en la Sierra de Atoyac, Guerrero. Thesis, Facultad de Ciencias, Universidad Nacional Autónoma de México, México, D.F.

Nowell, K., AND P. Jackson, (editors). 1996. Wild cats: status survey and conservation action plan. IUCN/ SSC Cat Specialist Group, International Union for the Conservation of Nature, Gland, Switzerland.

Ortega-Huerta, M. A., and K. E. Medley. 1999. Landscape analysis of jaguar (Panthera onca) habitat using sighting records in the Sierra de Tamaulipas, Mexico. Environmental Conservation 26:257-269.

Rosas-Rosas, O., and J. H. López-Soto. 2002. Distribución y estado de conservación del jaguar en Nuevo León, México. Pages 393-401 in El jaguar en el nuevo milenio (R. A. Medellín, C. Equihua, C. L. B. Chetkiewicz, G. Crawshaw, Jr., A. Rabinowitz, K. H. Redford, J. G. Robinson, E. W. Sanderson, and A. B. Taber, compilers, editors). Fondo de Cultura Económica, Universidad Nacional Autónoma y Ediciones Científicas Universitarias, México, D.F

Sánchez, Ó., J. Ramírez-Pulido, U. Aguilera-Reyes, and O. Monroy-Vilchis. 2002. Felid records from the state of Mexico, Mexico. Mammalia 66:289-294.

Sanderson, E., C. L. B. Chetkiewicz, R. Medellín, A. Rabinowitz, K. H. Redford, J. G. Robinson, and A. TABER. 2002a. Prioridades geográficas para la conservación del jaguar. Pages 601-628 in El jaguar en el nuevo milenio (R. A. Medellín, C. Equihua, C. L. B. Chetkiewicz, G. Crawshaw, Jr., A. Rabinowitz, K. H. Redford, J. G. Robinson, E. W. Sanderson, and A. B. Taber, compilers, editors). Fondo de Cultura
Económica, Universidad Nacional Autónoma y Ediciones Científicas Universitarias, México, D. F.

SAnderson, E., K. H. Redford, C. L. B. Chetkiewicz, R. A Medellín, A. Rabinowitz, R. J. G. Robinson, and A. B. TABER. 2002b. Planning to save a species: the jaguar as a model. Conservation Biology 16:58-72.

Secretaria del Medio Ambiente y Recursos Naturales. 2002. Norma oficial mexicana NOM-Ecol-059-2001, protección ambiental-especies nativas de México de flora y fauna silvestres-categorías de riesgo y especificaciones para su inclusión, exclusión o cambio-lista de especies en riesgo. Second edition. Diario Oficial de la Federación, 6de marzo de 2002, México, D.F..

Sunquist, M., AND F. Sunquist. 2002. Wild cats of the world. University of Chicago Press, London, United Kingdom.

Téllez-Girón, G., And W. López-Forment. 1995. Panthera onca veraecrucis (Carnivora: Felidae) en Querétaro, México. Revista Mexicana de Mastozoología 1: $73-75$.

Valdez, R., A. Martínez-Mendoza, and O. Rosas-Rosas. 2002. Componentes históricos y actuales del hábitat del jaguar en el noroeste de México. Pages 367-378 in El jaguar en el nuevo milenio (R. A. Medellín, C. Equihua, C. L. B. Chetkiewicz, G. Crawshaw, Jr., A. Rabinowitz, K. H. Redford, J. G. Robinson, E. W Sanderson, and A. B. Taber, compilers, editors). Fondo de Cultura Económica, Universidad Nacional Autónoma y Ediciones Científicas Universitarias, México, D.F.

Submitted 5 October 2006. Accepted 28 January 2008. Associate Editor was Cheri A. Jones. 